\title{
Examination of Students' Academic Motivation, Research Concerns and Research Competency Levels during the Education Period
}

\author{
Mustafa Durmuşçelebi \\ Faculty of Education, Erciyes University, Turkey
}

Copyright $\bigcirc 2018$ by authors, all rights reserved. Authors agree that this article remains permanently open access under the terms of the Creative Commons Attribution License 4.0 International License

\begin{abstract}
Nowadays, manpower, science and technology produced and innovation competence determine the development level of a society. Thus, abilities such as research curiosity, research talent, defining, analyzing and solving questions come to the forefront. The purpose of the study is analyzing the relations between students' academic motivation, research concerns and research competency levels in terms of various variables in the sample of Erciyes University. Screening model was used in the study. 727 senior class students from 13 faculties and 1 vocational high school participated in the study. Personal information form, academic motivation scale, research concern scale and research competency scale were used in the study as data collection tools. In data analysis, descriptive technics such as percentage, frequency and mean were used. Also, Pearson correlation coefficient was used to define relations between variables and T-test and analysis of variance (ANOVA) were used to reveal differentiations. Differences between groups were defined by Tukey test. Multiple regression analysis was used to define to what extent students' academic motivation and research concerns affect their research competency. In short, results of the study as follows: 1 . Students feel themselves ready for scientific studies with regard to academic motivation. However, proportion of the ones who are indecisive and do not feel ready is quite high; 2. Students state that they are not sure whether they have sufficient research concerns or not; 3 . Students state that they have sufficient research competency; 4. It was found out that students' academic motivation, research concern and competency scores did not differ according to their gender but they differed according to their faculties, departments, grade-point average and their level of satisfaction from departments; 5. It was found out that students' academic motivation, research concern and competency scores differed according to their status of taking scientific research methods course before. The ones
\end{abstract}

taking the course before had significantly higher scores; 6 . It was found out that $13 \%$ of students' academic competency was determined by academic motivation and research concern. Following suggestions can be made according to results: 1 . Events such as symposiums, panels and congresses can be organized to increase students' interest in doing scientific researches; 2. Studies should be done to define reasons of differentiation of students' academic motivation, research concerns and research competency levels according to their academic success, faculties and departments; 3. Courses such as scientific research, assessment and evaluation and statistics should be varied and put in the curriculums.

Keywords Academic Competency, Academic Motivation, Research Concern, Scientific Research

\section{Introduction}

In 21 st century which is also called information society period countries' development level and competitive power are measured by "raising a human, capacity of producing science, technology and innovation" rather than population, economical power and manpower (1). Development level of a country depends on manpower that it raises in the fields of science, education, industry and particularly technology, science and technology that it produces and the ability of producing new ideas and applying them (innovation) of its systems, mostitutions and people. Therefore, demand for higher education institutions has increased since 2000s. The increase in the number of university students in countries such as India and China (2) and the increase in the number of universities and university students in Turkey can be typical indicators 
of this situation.

To move with the times and not to stay behind in the future world the biggest responsibility falls to the higher education institutions. According to 1982 constitution act, higher education institutions are founded to raise manpower which fits the needs of nation and country. The most important function of these institutions is giving education, making scientific researches and consulting. Higher education institution is one of the most efficient institutions to build the future of a country in every aspect. Developments in science, art, literature, qualified labor force and technology depend on the proper working of the universities. The increase in demand for higher education in the world "becomes a policy in Turkey as well" (3) and there has been a high increase in the number of universities and students since 2000s.

There has been a significant increase in the number of higher education institutions and instructors since 2000. There were 56 public universities and 20 foundation universities in 2000. From professors to research assistants total number of instructors were 64.169. 25.162 of them were research assistants. In 2017, there were total 183 universities, 112 of them were public universities and 71 of them were foundation universities. The number of instructors were 153.967 with 46.455 research assistants. There has been increase more than $100 \%$ in the number of universities and more than $150 \%$ in the number of instructors (4). In addition, the increase in the number of graduate students attracts the attention. In 2000-2001 there were 65.068 graduate students, 21.739 doctoral students. In 2016-2017 there were 480.215 graduate students and 91.267 doctoral students (4).

Training instructors can be realized in different ways in Turkey; Higher Education Institution and/or Ministry of Education can send students abroad to study for master degree and these students can start working for the institutions that send them when they come back. Besides, universities can send students both by their programs and other universities' programs to do master degree. Besides, Higher Education Student Training Program which is a domestic or foreign graduate program can be counted as a synthesis of these three implementations (5).

In the last 20 years, unscientific steps have been taken in education system. Instead of the system's needs and developments in the world, politic issues came into prominence. As a result, the meaning of higher education became simpler. Universities became institutions which only transfer the knowledge instead of producing it. "The rise in the number of universities without sufficient instructors and other infrastructure planning lead to a lot of problems and several criticisms are made for this situation. Although establishing a university without sufficient instructors is not foreseen in development plans in Turkey, the practice is totally opposite to it" (6). It was believed that higher education problems could be solved by increasing the number of universities in Turkey, but this issue caused educating instructors and university's infrastructure problems. Universities have become places which cannot produce and use knowledge

As explanations mentioned above show the number of graduate students is one third of the total number of instructors since 2000. A study about how many of them join in production, in other words, how many of them join in the university administrative board or in other work field was not encountered. Since, universities have been seen as a key for having a job in recent years, students start doing master degree with some hope. There is not any study about what students are doing after master degree.

Success of higher education institutions highly depend on competencies of instructors and educating qualified instructors besides quantitative conditions. Qualifications of instructors are directly related to having certain knowledge and skills. To direct students to scientific research process is possible with scientific competencies, scientific culture and research desire which can be obtained in assessment and evaluation, scientific research methods and statistics courses. Therefore, students take the first step to be a scientist by means of those courses. Qualifications such as "learning scientific method, improving scientific thinking, having science ethic, producing and disseminating information and having science philosophy notion are some of the universal criteria of educating a scientist (7). Graduate education can only be accomplished by really desiring it, knowing scientific methods, having curiosity for scientific researches in short by having scientific thinking. To do necessary regulations in graduate education programs in parallel with educational, scientific and technological developments is one of the prerequisite for training qualified instructors who can produce universal information.

A great majority of students finish their education after undergraduate education or join in the business life or start graduate education to carry their education onward. Sometimes, students who join in business life before come back to graduate education and join in this process. Graduate education is a period which includes master degree, doctorate, proficiency in art, examinations for specialty in medicine, pharmaceutics, dentistry and veterinarian. Students enter into the process of education either directly after undergraduate education or after some time, it depends on the effects of their research education and research culture. "to do research requires specialty at a certain level; getting benefit from studies done, impressed by them and helping them requires general research culture. The education which is regulated for these general knowledge and specialty activities to be acquired is called research education" (8).

In short, it is expected in graduate education that students can do more comprehensive and more sound scientific studies than the ones during undergraduate 
education. Also it is expected that students can solve the problems by scientific ways, produce, analyze and synthesize information, have necessary methods and skills to solve problems that they encounter during their profession and to become expert. Since, these skills are needed both in scientific world and in business world. Today, graduate education has become important in recruitment process in business world. Therefore motivating graduate students, forming research culture, awareness and skill, shortly, train people having inquisitive manner and behaviors are some of the most important functions of this education process. "Undoubtedly, giving insight of research culture to students is a problem of education. Research education can be defined as an education which aims to form research consciousness in people and in society by making people gain scientific attitude and behavior and research competencies. Research competency can be stated as a component of research techniques, statistics, assessment and evaluation and computer domain." (9).

Today, making research, problem solving, reflective thinking and critical thinking skills are important to be taught to students in the frame of constructive education. The most important qualification of students who want to continue graduate education is research competency. Research competency is mentioned as a component of research technics, statistics, assessment and evaluation and computer (9). Studies (9, 10, 11), articles and papers display incompetence in research education significantly. There are a lot of students graduating from master degree without attending any conferences or panels, presenting any papers in scientific events or writing an article and publishing it. Studies shows that students participating in those kind of scientific events $(12,13)$ or taking scientific research course have higher attitude scores towards making a research than others $(11,14)$.

Scientific research methods, statistics and assessment and evaluation courses are courses that arouse curiosity in students, help students to solve the problems they face in their profession and show how to make a research in all its parts (problem, method, analysis and result). Results of the study carried out on teacher candidates (15) show that data collection and reporting have the highest competency score and data analysis and qualification of defining variables have the lowest competency score. It is seen that there are problems especially in method and analysis parts of the papers and articles and this situation supports results of the study.

\section{Purpose of the Study}

Today, Erciyes University is an institution giving service with its 19 faculties, 1 high school, 2 vocational schools of higher education, 7 institutes, 6 departments, 39 research centers and a 1350-bed research and application hospital.
Approximately, 2300 academic staff is working in the university and it has nearly 65.000 students. It is one of ten research centers in Turkey. Therefore, it was thought that it was a good sample for the research.

Purpose of the study is analyzing the relations between students' academic motivation level, research concern and research competency in Erciyes University. This study attempts to find answers to the questions below.

1. What is the level of students' academic motivation, research concern and research competency?

2. Does students' academic motivation, research concern and research competency level change according to their
A) Gender,
B) Faculty,
C) Department,
D) Grade-point average
E) Satisfaction from their departments
F) Their status of taking "Assessment and Evaluation", "Scientific Research Methods" and "Statistics" courses before.
3. To what extent students' academic motivation and research concerns affect their research competency?

\section{Materials and Methods}

\subsection{Research Model}

This study is a descriptive study done with screening model to reveal an existing situation. Relations between senior students' academic motivation, research concerns and research competency level in terms of various variables were tried to be described. Screening model is a model which aims to portray the pre-existing or existing situation and it does not make an effort to change or effect the situation (Karasar, 2014). This research is a portray of an existing situation.

\subsection{Population and Sample}

The population of the study consists of students from 18 faculties and 3 high schools in Erciyes University. There are approximately 60.000 students in 18 faculties, 7 institutions, 3 high schools and 10 vocational high schools of Erciyes University. 2274 instructors and research assistants are working in Erciyes University since February 2015. 853 of them are research assistants, namely, more than one third of the number. The sample of the study consists of 727 senior students from 13 faculties and 1 vocational high school. Students' distribution according to their faculties are represented in Table-1. 
Table 1. Students' gender and faculty

\begin{tabular}{|c|c|c|c|c|c|}
\hline \multirow{3}{*}{ Faculty and High School } & \multicolumn{4}{|c|}{ Gender } & \multirow{3}{*}{$\begin{array}{c}\text { Total } \\
\mathrm{n}\end{array}$} \\
\hline & \multicolumn{2}{|c|}{ Female } & \multicolumn{2}{|c|}{ Male } & \\
\hline & $\mathrm{n}$ & $\%$ & $\mathrm{n}$ & $\%$ & \\
\hline Faculty of Dentistry (FD) & 29 & 70,7 & 12 & 29,3 & 41 \\
\hline $\begin{array}{l}\text { Faculty of Pharmacy } \\
\text { (FP) }\end{array}$ & 24 & 66,7 & 12 & 33,3 & 36 \\
\hline $\begin{array}{l}\text { Faculty of Literature } \\
\qquad(\mathrm{FL})\end{array}$ & 50 & 82,0 & 11 & 18,0 & 61 \\
\hline $\begin{array}{l}\text { Faculty of Engineering } \\
\text { (FE) }\end{array}$ & 23 & 29,5 & 55 & 70,5 & 78 \\
\hline Faculty of Theology (FT) & 43 & 82,7 & 9 & 17,3 & 52 \\
\hline Faculty of Science (FS) & 27 & 77,1 & 8 & 22,9 & 35 \\
\hline $\begin{array}{c}\text { Faculty of } \\
\text { Communication (FC) }\end{array}$ & 34 & 46,6 & 39 & 53,4 & 73 \\
\hline $\begin{array}{l}\text { Faculty of Health } \\
\text { Sciences (FH) }\end{array}$ & 36 & 87,8 & 5 & 12,2 & 41 \\
\hline Faculty of Tourism (TF) & 26 & 61,9 & 16 & 38,1 & 42 \\
\hline $\begin{array}{l}\text { School of Aviation and } \\
\text { Space Science (SAS) }\end{array}$ & 4 & 13,3 & 26 & 86,7 & 30 \\
\hline $\begin{array}{l}\text { Faculty of Economics } \\
\text { and Administrative } \\
\text { Sciences (FEA) }\end{array}$ & 42 & 70,0 & 18 & 30,0 & 60 \\
\hline Faculty of Law (LF) & 16 & 33,3 & 32 & 66,7 & 48 \\
\hline $\begin{array}{l}\text { Faculty of Medicine } \\
\text { (FM) }\end{array}$ & 29 & 65,9 & 15 & 34,1 & 44 \\
\hline $\begin{array}{l}\text { Faculty of Education } \\
\text { (EF) }\end{array}$ & 56 & 65,1 & 30 & 34,9 & 86 \\
\hline Total & 439 & 60,4 & 288 & 39,6 & 727 \\
\hline
\end{tabular}

Table 1 shows that $60,4 \%$ of 727 participants are female and $39,6 \%$ of them are male. $47,7 \%$ of them study in social sciences, $30 \%$ of them study in natural sciences and $22,3 \%$ of them study in health sciences departments.

\subsection{Data Collection Tools}

"Academic Motivation Scale" developed by Bozanoğlu was used in the study to define students' academic motivation level (16). The scale was designed as five point likert scale (strongly inappropriate, inappropriate, neither appropriate or inappropriate, appropriate and strongly appropriate). Bozanoğlu defined reliability co-efficient is .86. Secondly, "Research Concern Scale" developed by Büyüköztürk was used in the study to define students' research concerns (17). The scale was also designed as five point likert scale "strongly agree-...-strongly disagree". There were totally 23 questions, 10 of them were positive and 13 of them were negative questions. Reliability co-efficient of the scale was found $\alpha=88$. The last data collection tool "Research Competency Scale" developed by Büyüköztürk was used to define students' research competencies. This scale consisted of 7 questions. Just as other scales developed by Büyüköztürk, this scale was also designed as five point likert scale and competencies were classified as "not at all", "slightly", "moderately", "very" and "extremely". Reliability coefficient of the scale is $\alpha=89$. There is "Personal Information Form" developed by the researcher. This form consisted of 6 items about study's independent variables. Grading key below was used in the classification of scales (Table 2).
Table 2. Grading Key of Research Scales

\begin{tabular}{ccccc}
\hline $\begin{array}{c}\text { Academic } \\
\text { Motivation }\end{array}$ & $\begin{array}{c}\text { Research } \\
\text { Concern }\end{array}$ & $\begin{array}{c}\text { Research } \\
\text { Competency }\end{array}$ & Grading \\
\hline $\begin{array}{c}\text { Strongly } \\
\text { inappropriate } \\
\text { Inappropriate } \\
\text { Neither }\end{array}$ & $\begin{array}{c}\text { Strongly } \\
\text { disagree } \\
\text { Disagree }\end{array}$ & Not at all & 1 & $1-1,8$ \\
$\begin{array}{c}\text { Neither } \\
\text { appropriate or } \\
\text { inappropriate } \\
\text { Appropriate }\end{array}$ & $\begin{array}{c}\text { Slightly } \\
\text { disagree } \\
\text { Strongly }\end{array}$ & Agree & 2 & $1,8-2,6$ \\
appropriate & $\begin{array}{c}\text { Strongly } \\
\text { agree }\end{array}$ & Extremely & 5 & $2,6-3,4$ \\
\hline
\end{tabular}

\subsection{Data Analysis}

Data was analyzed according to sub problems of the study. In data analysis process descriptive technics such as percentage, frequency and mean were used. Pearson correlation coefficient was used to define relations between variables. T-Test and Analysis of Variance (ANOVA) were used to reveal differentiations. Differences between groups were defined by Tukey test. Multiple regression analysis was used to define to what extent students' academic motivation and research concerns affect their research competency.

\section{Findings}

In this section test results of senior students' academic motivation, research concern and research competency levels and these levels' relations with students' genders, faculties, departments, grade-point average, satisfaction from departments and status of taking "Assessment and Evaluation", "Scientific Research Methods" and "Statistics" courses before are presented. Findings are revealed in line with the sub problems respectively.

Table 3 shows the test results of students' academic motivation, research concern and research competency level.

Qualifications of a researcher were asked to students in academic motivation scale. Table 3 shows that students feel themselves "appropriate" $(\bar{X}=3,43)$. However, the number of indecisive students is quite high (\% 43,2). Nearly half of $15 \%$ of students $(\% 7,4)$ think that they have researcher characteristics, while the other half $(\% 1,1+\%$ 6,3 ) thinks that they are not appropriate for being a researcher.

Students were asked how much a research idea and process make them excited, eager or uneasy in research concern scale. While students think that they are appropriate for being a researcher, they feel indecisive in the matters of research desire and excitement $(\bar{X}=2,89)$. It is concluded that students think they have the necessary qualifications for being a researcher but they are not sure that they have sufficient excitement. 
Table 3. Students' academic motivation, research concern and research competency level $(n=727)$

\begin{tabular}{|c|c|c|c|}
\hline & & $\mathrm{f}$ & $\%$ \\
\hline \multirow{7}{*}{ 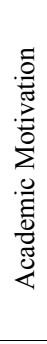 } & Strongly inappropriate & 8 & 1,1 \\
\hline & Inappropriate & 46 & 6,3 \\
\hline & $\begin{array}{l}\text { Neither appropriate or } \\
\text { inappropriate }\end{array}$ & 314 & 43,2 \\
\hline & Appropriate & 302 & 41,5 \\
\hline & Strongly Appropriate & 54 & 7,4 \\
\hline & $\overline{\mathbf{X}}$ & \multicolumn{2}{|c|}{3,43} \\
\hline & St. Dev. & \multicolumn{2}{|c|}{,60 } \\
\hline \multirow{7}{*}{ 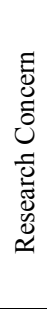 } & Strongly disagree & 8 & 1,1 \\
\hline & Disagree & 188 & 25,9 \\
\hline & Neither agree nor disagree & 443 & 60,9 \\
\hline & Agree & 74 & 10,2 \\
\hline & Strongly agree & 14 & 1,9 \\
\hline & $\overline{\mathbf{X}}$ & \multicolumn{2}{|c|}{2,89} \\
\hline & St. Dev. & \multicolumn{2}{|c|}{, 50} \\
\hline \multirow{7}{*}{ 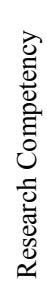 } & Not at all & 10 & 1,4 \\
\hline & Slightly & 75 & 10,3 \\
\hline & Moderately & 244 & 33,6 \\
\hline & Very & 297 & 40,9 \\
\hline & Extremely & 101 & 13,9 \\
\hline & $\overline{\mathbf{X}}$ & \multicolumn{2}{|c|}{3,45} \\
\hline & St. Dev. & \multicolumn{2}{|c|}{,73 } \\
\hline
\end{tabular}

Behaviors in research process were asked to students in research competency scale. More than half of the students $(\%$ $40,9+\% 13,9)$ think that they are "very" sufficient $(\overline{\mathrm{X}}=3,45)$ in this subject.

As it can be understood from the findings in the table, students do not have a definitive thought about academic motivation, research concern and research competency. It can stem from the fact that students do not get sufficient information or they do not see their future in higher education. However, it cannot be forgotten that a person graduating from higher education must have these characteristics.

Table 4 shows t-test results done to define differences in academic motivation, research concern and research competency levels by gender.

Table 4. T-Test results in terms of gender

\begin{tabular}{|c|c|c|c|c|c|c|}
\hline \multirow{2}{*}{ Variable } & \multirow{2}{*}{$\mathrm{G}$} & \multirow{2}{*}{$\mathrm{N}$} & \multirow{2}{*}{$\bar{X}$} & \multirow{2}{*}{$\mathrm{SD}$} & \multicolumn{2}{|c|}{$\mathrm{t}-$ test } \\
\hline & & & & & $\mathrm{t}$ & $\mathrm{p}$ \\
\hline Academic & $\mathrm{F}$ & 439 & 3,42 & ,588 & & \\
\hline $\begin{array}{c}\text { Motivation } \\
\text { Level }\end{array}$ & M & 288 & 3,43 &, 620 &,- 288 &, 774 \\
\hline Research & $\mathrm{F}$ & 439 & 2,87 &, 503 & & \\
\hline $\begin{array}{c}\text { Concern } \\
\text { Level }\end{array}$ & $\mathrm{M}$ & 288 & 2,91 & ,492 & $-1,188$ & ,235 \\
\hline Research & $\mathrm{F}$ & 439 & 3,46 &, 716 & & \\
\hline $\begin{array}{c}\text { Competency } \\
\text { Level }\end{array}$ & $\mathrm{M}$ & 288 & 3,44 & ,737 & ,442 & ,658 \\
\hline
\end{tabular}

$\mathrm{p}<, 05$ (G: Gender; F: Female; M: Male)
Table 4 shows that there is no meaningful difference between students' opinions about academic motivation, research concern and research competency levels in terms of their gender. While, male students feel themselves closer to being a researcher compared to female students in academic motivation and research concern, female students feel themselves more competent on research competency compared to males.

Table 5 shows Anova test results done to define differences in academic motivation scores in terms of faculties.

Table 5. Anova test results of students' academic motivation in terms of faculties

\begin{tabular}{|c|c|c|c|c|c|c|c|}
\hline $\mathrm{L}$ & $\mathrm{Gr}$ & $\mathrm{N}$ & $\overline{\mathrm{X}}$ & $\mathrm{Sd}$ & $\mathrm{F}$ & $\mathrm{p}$ & Dif. \\
\hline \multirow{15}{*}{ 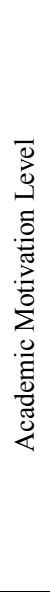 } & FD & 41 & 3,19 & ,570 & \multirow{15}{*}{2,96} & \multirow{15}{*}{,000 } & \multirow[t]{2}{*}{ FL } \\
\hline & $\mathrm{FP}$ & 36 & 3,28 & ,484 & & & \\
\hline & FL & 61 & 3,62 & ,638 & & & \multirow[t]{8}{*}{$\mathrm{FD}, \mathrm{LF}$} \\
\hline & $\mathrm{FE}$ & 78 & 3,48 & ,585 & & & \\
\hline & FT & 52 & 3,53 & 647 & & & \\
\hline & FS & 35 & 3,55 & 600 & & & \\
\hline & $\mathrm{FC}$ & 73 & 3,48 & ,619 & & & \\
\hline & $\mathrm{FH}$ & 41 & 3,55 & ,468 & & & \\
\hline & $\mathrm{TF}$ & 42 & 3,32 & ,547 & & & \\
\hline & SAS & 30 & 3,44 & ,566 & & & \\
\hline & FEA & 60 & 3,58 & ,559 & & & \multirow{5}{*}{$\begin{array}{c}\text { LF } \\
\text { FEA, FL }\end{array}$} \\
\hline & $\mathrm{LF}$ & 48 & 3,19 & ,465 & & & \\
\hline & $\mathrm{FM}$ & 44 & 3,39 & ,724 & & & \\
\hline & $\mathrm{EF}$ & 86 & 3,30 & 633 & & & \\
\hline & Tot. & 727 & 3,43 & ,601 & & & \\
\hline
\end{tabular}

$\mathrm{p}<, 05$

Table 5 shows that there is a meaningful difference between students' academic motivation scores in terms of their faculties. Tukey test results indicate that there are significant differences between scores of students of Faculty of Literature and Faculty of Dentistry and between scores of students of Faculty of Law and Faculty of Economics and Administrative Sciences. The highest academic motivation score belongs to Faculty of Literature $(\overline{\mathrm{X}}=3,62)$ and Faculty of Economics and Administrative Sciences $(\overline{\mathrm{X}}=3,58)$ students. Students of both faculties express that they are more appropriate than others. The lowest academic motivation score belongs to Faculty of Dentistry $(\bar{X}=3,19)$ and Faculty of Law $(\bar{X}=3,19)$ students. These students are indecisive about having academic motivation behaviors.

Table 5 shows that students having higher university entrance exam score have lower academic motivation scores than students having lower university entrance exam score. According to present situation, it can be said that students studying at social sciences have higher confidence in academic motivation. Reasons of this situation should be studied.

Table 6 shows Anova test results done to define differences in research concern scores in terms of faculties. 
Table 6. Anova test results of students' research concern in terms of faculties

\begin{tabular}{|c|c|c|c|c|c|c|c|}
\hline $\mathrm{L}$ & $\mathrm{Gr}$ & $\mathrm{N}$ & $\overline{\mathrm{X}}$ & $\mathrm{Sd}$ & $\mathrm{F}$ & $\mathrm{p}$ & Dif. \\
\hline \multirow{15}{*}{ 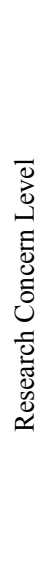 } & FD & 41 & 2,82 & ,409 & \multirow{15}{*}{18,391} & \multirow{15}{*}{, 000} & $\mathrm{EF}$ \\
\hline & FP & 36 & 2,91 & ,363 & & & $\mathrm{EF}$ \\
\hline & FL & 61 & 2,75 & ,411 & & & $\mathrm{EF}$ \\
\hline & FE & 78 & 2,77 & ,344 & & & $\mathrm{EF}$ \\
\hline & FT & 52 & 2,73 & ,405 & & & $\mathrm{EF}$ \\
\hline & FS & 35 & 2,69 & ,412 & & & $\mathrm{EF}$ \\
\hline & $\mathrm{FC}$ & 73 & 2,83 & ,397 & & & $\mathrm{EF}$ \\
\hline & FH & 41 & 2,81 & ,281 & & & $\mathrm{EF}$ \\
\hline & $\mathrm{TF}$ & 42 & 2,82 & ,301 & & & $\mathrm{EF}$ \\
\hline & SAS & 30 & 2,84 & ,460 & & & $\mathrm{EF}$ \\
\hline & FEA & 60 & 2,77 & ,322 & & & $\mathrm{EF}$ \\
\hline & LF & 48 & 2,96 & ,400 & & & $\mathrm{EF}$ \\
\hline & FM & 44 & 2,72 & 2 & & & $\mathrm{EF}$ \\
\hline & EF & 86 & 3,55 & ,748 & & & All \\
\hline & Tot. & 727 & 2,89 & 499 & & & \\
\hline
\end{tabular}

$\mathrm{p}<, 05$

Table 6 shows that there is a meaningful difference between students' research concern scores in terms of their faculties. Tukey test results indicate that there are significant differences between scores of students of Faculty of Education $(\overline{\mathrm{X}}=3,19)$ and other faculties. While students of Faculty of Education express that they have research concern behaviors, students of other faculties are indecisive. The lowest research concern score belongs to Faculty of Science students $(\overline{\mathrm{X}}=2,69)$. Faculties general average $(\bar{X}=2,89)$ shows that students are "indecisive" about having research concern behaviors. The reason of education faculty students' high research concern scores can be that courses which can increase the concern take larger place.

Table 7 shows Anova test results done to define differences in research competency scores in terms of faculties.

Table 7. Anova test results of students' research competency in terms of faculties

\begin{tabular}{|c|c|c|c|c|c|c|c|}
\hline $\mathrm{L}$ & Gr & $\mathrm{N}$ & $\bar{X}$ & $\mathrm{Sd}$ & $\mathrm{F}$ & $\mathrm{p}$ & Dif. \\
\hline \multirow{15}{*}{ 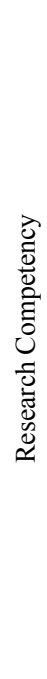 } & FD & 41 & 2,94 & ,762 & \multirow{15}{*}{5,58} & \multirow{15}{*}{, 000} & FL, FE, FS \\
\hline & FP & 36 & 3,31 & ,730 & & & $\begin{array}{c}\mathrm{FC}, \mathrm{TF}, \\
\text { FEA }\end{array}$ \\
\hline & FL & 61 & 3,57 &, 714 & & & $\mathrm{EF}$ \\
\hline & $\mathrm{FE}$ & 78 & 3,59 &, 737 & & & \\
\hline & FT & 52 & 3,29 &, 760 & & & FD \\
\hline & FS & 35 & 3,83 &, 775 & & & FD \\
\hline & $\mathrm{FC}$ & 73 & 3,46 & ,674 & & & FS,FEA \\
\hline & $\mathrm{FH}$ & 41 & 3,15 &, 753 & & & $\begin{array}{c}\mathrm{FD}, \mathrm{FT}, \\
\mathrm{FH}\end{array}$ \\
\hline & $\mathrm{TF}$ & 42 & 3,49 & ,653 & & & LF, FM \\
\hline & SAS & 30 & 3,48 &, 561 & & & FD \\
\hline & FEA & 60 & 3,77 &, 738 & & & FS, FEA \\
\hline & $\mathrm{LF}$ & 48 & 3,27 &, 602 & & & FD \\
\hline & FM & 44 & 3,23 & ,567 & & & \multirow{3}{*}{$\begin{array}{c}\text { FD, FT, } \\
\text { FH }\end{array}$} \\
\hline & $\mathrm{EF}$ & 86 & 3,57 & ,654 & & & \\
\hline & Tot. & 727 & 3,45 &, 724 & & & \\
\hline
\end{tabular}

Table 7 shows that there is a meaningful difference between students' research competency scores in terms of their faculties. Tukey test results indicate that there are significant differences between almost all the faculties' students with students from other faculties. There is a significant difference between Faculty of Science $(\bar{X}=3,83)$ and Faculty of Economics and Administrative Sciences $(\bar{X}=3,77)$ students and Faculty of Dentistry students $(\bar{X}=2,94)$ having the lowest mean. While faculty of dentistry, faculty of pharmacy, faculty of theology, faculty of health science, faculty of law, faculty of medicine students express that they have research competency behaviors "moderately", others express that they have those behaviors "very". It is seen that students of two faculties having the lowest university entrance exam scores have higher research competency score than students of other faculties. Students having lower university entrance exam scores can have high confidence.

Table 8 shows Anova test results done to define differences in academic motivation, research concern and research competency scores in terms of departments

Table 8. Anova test results of students' academic motivation, research concern and research competency levels in terms of departments

\begin{tabular}{|c|c|c|c|c|c|c|c|}
\hline $\mathrm{L}$ & $\mathrm{Gr}$ & $\mathrm{N}$ & $\overline{\mathrm{X}}$ & $\mathrm{Sd}$ & $\mathrm{F}$ & $\mathrm{p}$ & Dif. \\
\hline \multirow{4}{*}{ 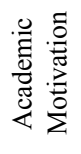 } & SS & 347 & 3,46 & ,603 & \multirow{4}{*}{ 导 } & \multirow{4}{*}{$\stackrel{n}{2}$} & \\
\hline & NS & 218 & 3,43 & ,605 & & & \\
\hline & HS & 162 & 3,35 & ,587 & & & \\
\hline & Tot & 727 & 3,43 & ,601 & & & \\
\hline \multirow{4}{*}{ 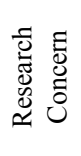 } & SS & 347 & 2,95 &, 535 & \multirow{4}{*}{ 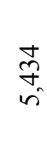 } & \multirow{4}{*}{$\stackrel{n}{8}$} & NS, HS \\
\hline & NS & 218 & 2,85 &, 521 & & & SS \\
\hline & HS & 162 & 2,81 & ,354 & & & SS \\
\hline & Tot & 727 & 2,89 & ,499 & & & \\
\hline \multirow{4}{*}{ 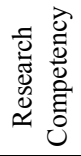 } & SS & 347 & 3,55 &, 705 & \multirow{4}{*}{$\begin{array}{l}\infty \\
\infty \\
\sim \\
\infty \\
\infty\end{array}$} & \multirow{4}{*}{8} & HS \\
\hline & NS & 218 & 3,52 & ,708 & & & HS \\
\hline & HS & 162 & 3,16 &, 710 & & & $\mathrm{SS}, \mathrm{NS}$ \\
\hline & Tot & 727 & 3,45 &, 724 & & & \\
\hline
\end{tabular}

Table 8 shows that while there is not a significant difference between students' academic motivation scores in terms of their departments, there are significant differences between their research concern and research competency scores in terms of their departments. Students from social sciences departments $(\bar{X}=2,95)$ have higher scores than students in other departments $(\bar{X}=2,85$; $\bar{X}=2,81$ ). According to Tukey test results the differences are in between social sciences departments' mean and the other two departments' means.

Students from health sciences departments have lower mean $(\bar{X}=3,16)$ than the students from other two departments social $(\bar{X}=3,55)$ and natural sciences $(\bar{X}=3,52)$. As a result of Tukey test differences are in between health sciences departments' mean and the other two departments' means. Health sciences faculty is one of the faculties which accepts students having the highest university entrance exam scores. Students of this faculty have lower scores in academic motivation, research concern and research competency. The reasons of this 
situation must be studied.

Table 9. Anova test results of students' academic motivation, research concern and research competency levels in terms of grade point average

\begin{tabular}{|c|c|c|c|c|c|c|c|}
\hline $\mathrm{L}$ & $\mathrm{Gr}$ & $\mathrm{N}$ & $\bar{X}$ & $\mathrm{Sd}$ & $\mathrm{F}$ & $\mathrm{p}$ & Dif. \\
\hline \multirow{6}{*}{ 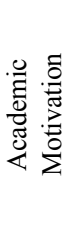 } & $\mathrm{CC}$ & 136 & 3,30 & 543 & \multirow{6}{*}{ 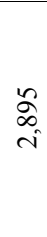 } & \multirow{6}{*}{$\bar{\delta}$} & $\mathrm{BB}$ \\
\hline & $\mathrm{CB}$ & 343 & 3,42 & ,607 & & & \multirow{17}{*}{$\mathrm{CC}$} \\
\hline & BB & 192 & 3,53 & ,560 & & & \\
\hline & BA & 44 & 3,45 &, 731 & & & \\
\hline & $\mathrm{AA}$ & 12 & 3,43 & 933 & & & \\
\hline & Tot. & 727 & 3,43 & ,601 & & & \\
\hline \multirow{6}{*}{ 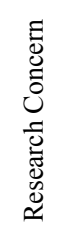 } & $\mathrm{CC}$ & 136 & 2,86 & ,453 & \multirow{6}{*}{$\underset{\sim}{\stackrel{\sim}{f}}$} & \multirow{6}{*}{$\overrightarrow{\widetilde{N}}$} & \\
\hline & $\mathrm{CB}$ & 343 & 2,88 & ,459 & & & \\
\hline & $\mathrm{BB}$ & 192 & 2,92 & ,512 & & & \\
\hline & BA & 44 & 2,96 & 686 & & & \\
\hline & AA & 12 & 2,63 & 905 & & & \\
\hline & Tot. & 727 & 2,89 & ,499 & & & \\
\hline \multirow{6}{*}{ 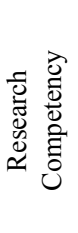 } & $\mathrm{CC}$ & 136 & 3,40 & ,795 & \multirow{6}{*}{$\underset{\overbrace{}}{0}$} & \multirow{6}{*}{$\stackrel{n}{n}$} & \\
\hline & $\mathrm{CB}$ & 343 & 3,48 &, 707 & & & \\
\hline & BB & 192 & 3,40 & ,689 & & & \\
\hline & BA & 44 & 3,48 & ,763 & & & \\
\hline & AA & 12 & 3,88 & 675 & & & \\
\hline & Tot. & 727 & 3,45 &, 724 & & & \\
\hline
\end{tabular}

$\mathrm{p}<, 05$

Table 9 shows Anova test results done to define differences in academic motivation, research concern and research competency scores in terms of grade point average.

Tablo 9 shows that there is a significant difference only in academic motivation scores in terms of their grade point average. According to Tukey test results the difference is between students having the lowest GPA (CC) $(\overline{\mathrm{X}}=3,30)$ and having medium GPA $(\mathrm{BB})(\overline{\mathrm{X}}=3,53)$. Students having the highest GPA (AA) have lower academic motivation score mean $(\bar{X}=3,43)$ than the ones having medium GPA $(\mathrm{BB})$.

Table 10 shows Anova test results done to define differences in academic motivation, research concern and research competency scores in terms of satisfaction from departments.

Table 10. Anova test results of students' academic motivation, research concern and research competency levels in terms of satisfaction from departments

\begin{tabular}{|c|c|c|c|c|c|c|c|}
\hline $\mathrm{L}$ & $\mathrm{Gr}$ & $\mathrm{N}$ & $\overline{\mathrm{X}}$ & $\mathrm{Sd}$ & $\mathrm{F}$ & $\mathrm{p}$ & Dif \\
\hline \multirow{4}{*}{ 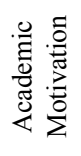 } & 1. Yes & 370 & 3,56 & 619 & \multirow{4}{*}{ 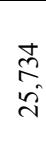 } & \multirow{4}{*}{8} & 2,3 \\
\hline & 2. Part & 286 & 3,34 & ,515 & & & 1,3 \\
\hline & 3. No & 71 & 3,07 & ,632 & & & 1,2 \\
\hline & Tot. & 727 & 3,43 & ,601 & & & \\
\hline \multirow{4}{*}{ 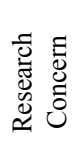 } & 1. Yes & 370 & 2,88 &, 540 & \multirow{4}{*}{$\begin{array}{l}\overrightarrow{\mathrm{g}} \\
\text { ते }\end{array}$} & \multirow{4}{*}{$\tilde{n}$} & \\
\hline & 2. Part & 286 & 2,86 & ,423 & & & 3 \\
\hline & 3. No & 71 & 3,02 & ,543 & & & 2 \\
\hline & Tot. & 727 & 2,89 & ,499 & & & \\
\hline \multirow{4}{*}{ 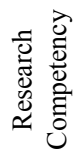 } & 1. Yes & 370 & 3,47 & 698 & \multirow{4}{*}{$\frac{0}{n}$} & \multirow{4}{*}{$\hat{\infty}$} & \\
\hline & 2. Part & 286 & 3,43 & ,707 & & & \\
\hline & 3. No & 71 & 3,42 & 910 & & & \\
\hline & Tot. & 727 & 3,45 &, 724 & & & \\
\hline
\end{tabular}

As it is seen from table 10, students' academic motivation, research concern and research competency scores are analyzed. It is found out that there is a significant difference between students' academic motivation scores and their satisfaction from departments. There are significant differences between all these three groups scores, student who are satisfied from their departments $(\overline{\mathbf{X}}=3,56)$, who are partially satisfied from their departments $(\overline{\mathbf{X}}=3,34)$ and who are not satisfied from their departments $(\overline{\mathbf{X}}=3,07)$.

One of the most important sub problems of the study is whether there is a difference between students' academic motivation, research concern and research competency scores and their status of taking scientific research methods, assessment and evaluation and statistics courses before. Table 11 shows details regarding mentioned score variance.

Scientific Research Methods course is given in every department in Erciyes University. However, assessment and evaluation course is not given in every department, some subjects of the course are given as a part of statistics course. Table 11 shows that while there is not a significant difference between students' academic motivation score and their status of taking assessment and evaluation and statistics course before, there is a significant difference between students' academic motivation score and their status of taking scientific research course before. Students taking scientific research course before have higher academic motivation score mean $(\overline{\mathrm{X}}=3,83)$ than the ones not taking the course before $(\overline{\mathrm{X}}=3,83)$.

Table 11. T-test results of students' academic motivation, research concern and research competency levels in terms of their status of taking scientific research methods, assessment and evaluation and statistics courses before

\begin{tabular}{|c|c|c|c|c|c|c|c|c|}
\hline $\mathrm{L}$ & $\mathrm{Gr}$ & Ans & $\mathrm{N}$ & $\bar{X}$ & $\mathrm{Sd}$ & $\mathrm{t}$ & $\mathrm{df}$ & $\mathrm{p}$ \\
\hline \multirow{6}{*}{ 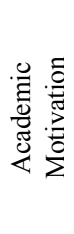 } & \multirow{2}{*}{ 昰 } & Yes & 268 & 3,45 & ,63 & \multirow{2}{*}{,799 } & \multirow{2}{*}{725} & \multirow{2}{*}{,425 } \\
\hline & & No & 459 & 3,41 &, 58 & & & \\
\hline & \multirow{2}{*}{$\sum_{\sim}^{\sim}$} & Yes & 383 & 3,47 & ,65 & \multirow{2}{*}{2,076} & \multirow{2}{*}{725} & \multirow{2}{*}{, 038} \\
\hline & & No & 344 & 3,38 &, 54 & & & \\
\hline & \multirow{2}{*}{$\Omega$} & Yes & 344 & 3,40 & ,61 & \multirow{2}{*}{$-1,274$} & \multirow{2}{*}{725} & \multirow{2}{*}{ 203 } \\
\hline & & No & 383 & 3,45 & ,59 & & & \\
\hline \multirow{6}{*}{ 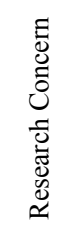 } & \multirow{2}{*}{ 昰 } & Yes & 268 & 3,00 & ,64 & \multirow{2}{*}{4,524} & \multirow{2}{*}{725} & \multirow{2}{*}{, $000 *$} \\
\hline & & No & 459 & 2,82 & ,38 & & & \\
\hline & \multirow{2}{*}{$\sum_{\widetilde{d}}$} & Yes & 383 & 2,94 & ,58 & \multirow{2}{*}{2,809} & \multirow{2}{*}{725} & \multirow{2}{*}{, $005^{*}$} \\
\hline & & No & 344 & 2,83 & ,38 & & & \\
\hline & \multirow{2}{*}{ 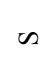 } & Yes & 344 & 2,86 & ,48 & \multirow{2}{*}{$-1,470$} & \multirow{2}{*}{725} & \multirow{2}{*}{,142 } \\
\hline & & No & 383 & 2,91 &, 52 & & & \\
\hline \multirow{6}{*}{ 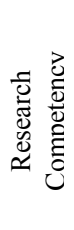 } & $\mu$ & Yes & 268 & 3,49 & ,72 & \multirow{2}{*}{1,160} & \multirow{2}{*}{725} & \multirow{2}{*}{,246 } \\
\hline & & No & 459 & 3,43 &, 72 & & & \\
\hline & \multirow{2}{*}{$\sum_{\tilde{\sigma}}$} & Yes & 383 & 3,58 & ,73 & \multirow{2}{*}{5,379} & \multirow{2}{*}{725} & \multirow{2}{*}{, $000 *$} \\
\hline & & No & 344 & 3,30 & ,69 & & & \\
\hline & \multirow{2}{*}{$\sim$} & Yes & 344 & 3,48 &, 74 & 1055 & 725 & 292 \\
\hline & & No & 383 & 3,42 &, 71 & & & \\
\hline
\end{tabular}

* $\mathrm{p}<, 05$ - AE: Assessment and Evaluation; SRM: Scientific Research Methods; S: Statistics.

It can be understood from table 11 that there is a significant difference between students' research concern 
score and their status of taking assessment and evaluation and scientific research methods course before. Students taking the course before have higher score mean $(\overline{\mathrm{X}}=3,00$; $\bar{X}=2,94)$ than the ones not taking the course before $(\bar{X}=2,82$; $\overline{\mathrm{X}}=2,83$ ). Students taking statistics course before have lower score $(\overline{\mathrm{X}}=2,86)$ than the ones not taking the course before $(\overline{\mathrm{X}}=2,91)$.

Students taking all these three courses before have higher research competency scores than the ones not taking the courses. However, there is only a significant difference between scores of students taking scientific research course before $(\bar{X}=3,58)$ and students not taking the course before $(\overline{\mathrm{X}}=3,30)$.

While defining research problems it was thought that academic motivation and research concern could affect students' research competency, so it was tried to be identified to what extent both variables affected research competency. Therefore, regression analysis was done. Table 12 presents results of the regression analysis.

Table 12. Regression analysis results of students' academic motivation and research concern levels effects on research competency level

\begin{tabular}{|c|c|c|c|c|c|c|c|}
\hline 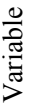 & B & SHB & $\beta$ & $\mathrm{T}$ & $\mathrm{p}$ & $\begin{array}{c}\text { Multiple } \\
\text { r }\end{array}$ & $\begin{array}{c}\text { Partial } \\
\text { R }\end{array}$ \\
\hline
\end{tabular}

$\begin{array}{llll}\frac{0}{\text { 苟 }} & 1,774 & , 218 & 8,121\end{array}$

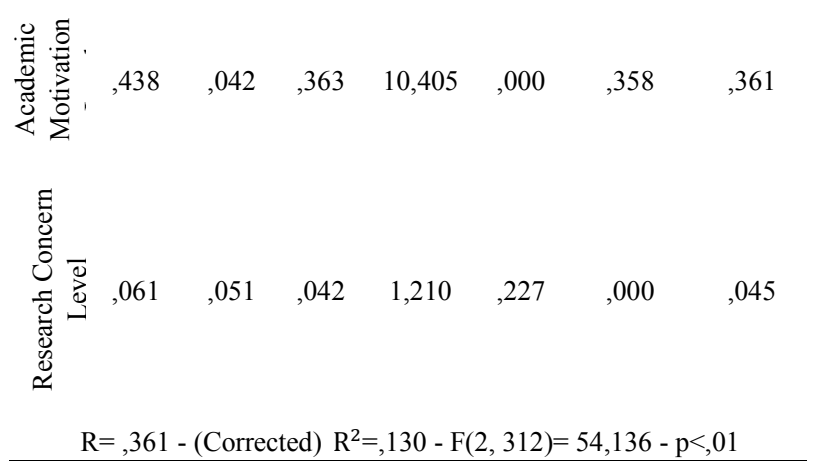

Table 12 shows that $\left(\mathrm{R}^{2}=, 130\right) 13 \%$ of variation in research competency level can be expressed by other two variables. When research concern levels are fixed, one standard deviation increase in academic motivation level cause $\beta=, 363$ ss increase in study's dependent variable research competency level. Also, when academic motivation levels are fixed, one standard deviation increase in research concern level cause $\beta=, 042$ ss increase in study's dependent variable research competency. It can be concluded that academic motivation level has higher effect on dependent variable.

\section{Conclusions}

In this section, results of the study presented. Results are given in line with the sub problems respectively.

\section{Students' Academic Motivation, Research Concern and Research Competency Levels}

According to findings there is not a consensus among students regarding academic motivation. When total scores are analyzed it is seen that majority of students are ready for academic studies, on the other hand, almost half of the students are "neither appropriate or inappropriate" and they are not mature enough for academic motivation. According to answers of the questions which are asked to define to what extent students have research concern, students do not have sufficient research concern. When academic motivation and research concern levels are taken together, it can be said that students feel themselves appropriate for academic studies but they do not have the responsibility yet. Finally, the results of the test done to define whether students have competency for making a research shows that students feel themselves very competent with regard to research competency. It implies that students have high self-confidence.

Parallelism is seen among the studies in the literature (10, $11,13)$ and this study. Studies made with graduate and undergraduate students show that desire for post graduate education effect attitude for research positively, and there is a positive relationship between research experience and research attitude (19). In addition, studies show that while sufficient level is reached in academic motivation, sufficient level is not reached in research competency.

As it can be seen in the studies of Karasar (8) and Büyüköztürk and Köklü (9) sufficient improvement could not be made in research education; sufficient research concern and research competency level was not developed even though there was sufficient interest and desire. To increase the number and credits of courses which can increase research competency and research concern levels, to teach those courses more seriously and to make those courses prerequisite for beginning scientific studies can be some ways of the solution of this problem. In addition, research homework can be given since primary education to develop research attitudes of students.

\section{Differences of Academic Motivation, Research Concern and Research Competency Levels in terms of Some Variables}

It can be said that there is not a significant difference between students' academic motivation, research concern and research competency scores and their gender. It can be claimed that partially, male students are more ready for scientific studies. As a result of the test done to see if there is a significant difference between students' academic motivation level and their faculties it is seen that students from faculties having more job opportunities have higher scores than the students from faculties having limited job opportunities. For instance, students from faculties having limited job opportunities such as faculty of science and 
faculty of economics and administrative sciences have higher academic motivation, research concern and research competency scores than students from faculty of dentistry and faculty of law. This can be because of the fact that students think being an academician is a job opportunity.

As a result of the test done to compare students' research concern scores with their faculties it is seen that students from faculty of education have higher scores than students from other faculties. Why students of faculty of education have higher level of research concern is a subject which is thought to be studied.

It is found out that students from faculties having more job opportunities have lower scores than the ones from faculties having less job opportunities. It can be inferred that students having more job opportunities want to begin to work directly after university.

When academic motivation, research concern and research competency scores are compared with students' departments, it is found out that students studying in social sciences departments have higher scores than others. It can be considered that students want to do academic studies as they have limited job opportunities. Other variables seem to support this argument.

Students' grade point average is handled as another sub-problem, because it was assumed that successful students think of having an academic career more than other students. As a result of the test, scores of students having lowest GPA are significantly lower than the students having medium GPA only in academic motivation variable. Academic success variable does not make any difference in other two dimensions.

It was assumed that students' satisfaction from their departments could lead students to academic studies. Therefore, it was handled as another sub-problem. There are significant differences between students' academic motivation, research concern and research competency scores and their satisfaction from departments. In research concern dimension, it is found out that there are significant differences between students partially satisfied and not satisfied from their departments. According to these results it can be claimed that students' satisfaction from their departments lead them to academic studies more.

Scientific research methods course is given in every department in the university. Assessment and evaluation and statistics courses are given in many departments. Scientific research methods course is a thought-provoking course. It makes students gain research competency and encourages them to make academic studies more. Therefore, these three courses are handled as a separate variable in the study. It is found out that students taking scientific research methods course have higher scores than students not taking the score in all three dimensions. It can be assumed that scientific research methods course can lead students to academic studies.

Last sub-problem of the study is to what extent students' academic motivation and research concern level affect their research competency level. According to results of the test, it can be said that academic motivation and research concern affect students' research competency $13 \%$.

As a result, it is found out that there is a difference between academic motivation, research concern and research competency scores of students of social sciences and students of natural sciences and between students who are satisfied with their departments and who are not satisfied with their departments, in other words students who study in departments having more job opportunities and having less job opportunities. According to these results, it can be stated that particularly students' job concern can affect their research desire. It can be thought that students having job concern think university as a key for having a job, therefore they have high level of academic motivation, research concern and research competency. However, scientific thought should not take a shape according to job concern. Students' academic motivation, research concern and research competency show a perspective. To give point of view to students is among the functions of courses such as scientific research methods, statistics and assessment and evaluation courses. Also, the study shows that there is a difference between scores of students who take scientific research methods course and who do not. Projects and activities which can make students have investigative personality should be done since primary education years. In addition, these courses' variety and credits can be increased in universities.

\section{REFERENCES}

[1] Günay, D., \& Günay, A. (Nisan/April 2016). Dünyada ve Türkiye'de Yükseköğretim Okullaşma Oranları ve Gelişmeler. Yükseköğretim ve Bilim Dergisi / Journal of Higher Education and Science, 6(1), 13-30.

[2] Daniel, J., Kanwar, A., \& Uvalić-Trumbić, S. (March/April, 2009). Breaking Higher Education's Iron Triangle: Access, Cost and Quality. Change., 30-35.

[3] Ekinci, C. E. (2011). Bazı Sosyoekonomik Etmenlerin Türkiye'de Yükseköğretime Katılım Üzerindeki Etkileri. Eğitim ve Bilim, 36(160), 281-297.

[4] YÖK. (2017, 11 23). Yükseköğretim Bilgi Yönetim Sistemi: https://istatistik.yok.gov.tr/ adresinden alındı

[5] ODTÜ Araştırmalar Koordinatörlüğü. (2013). ÖYP-YÖK Kaynak Kullanımı ile ilgili Bilgi Kılavuzu. Ankara: Orta Doğu Teknik Üniversitesi. 7 14, 2018 tarihinde http://oyp.metu.edu.tr adresinden alınd 1

[6] Karakütük, K., \& Özdemir, Y. (2011). Bilim İnsanı Yetiştirme Projesi (BIYYEP) ve Öğretim Üyesi Yetiştirme Programı'nın (ÖYP) Değerlendirilmesi. Ĕgitim ve Bilim, 36(161), 26-38.

[7] Tanker, M. (2001). Sağlık bilimleri alanında bilim adamı yetiştirme. Bilim Adamı Yetiştirme: Lisansüstü Eğitim. , 
$77-81$.

[8] Karasar, N. (2014). Bilimsel Araştırma Yöntemi (27b.). Ankara: Nobel Yayıncılik.

[9] Büyüköztürk, Ş., \& Köklü, N. (1999). Eğitim Bilimleri Alanında Öğrenim Gören Lisansüstü Öğrencilerinin Araştırma Yeterlikleri Konusunda Öğretim Üyelerinin Görüşleri. Eğitim ve Bilim, 23(112), 18-28. 7 14, 2018 tarihinde

http://egitimvebilim.ted.org.tr/index.php/EB/issue/view/106 adresinden alınd 1

[10] Saracaloğlu, A. S. (2005). Beden Eğitimi Öğretmeni Adaylarının Araştırmaya Yönelik Tutumları ve Deneyimleri İle Araştırma Başarıları Arasındaki İlişki. Gazi Üniversitesi Beden Eğitimi ve Spor Bilimleri Dergisi, 10(4), 13-32.

[11] Saracaloğlu, A. S., Varol, S. R., \& Ercan, İ. E. (2005). Lisansüstü Eğitim Öğrencilerinin Araştırma Kaygıları, Araştırma ve İstatistiğe Yönelik Tutumları ile Araştırma Yeterlikleri Arasındaki İlişki. Buca Eğitim Fakültesi Dergisi. Özel Sayl(17), 187-199.

[12] Bard, C., Bieschke, K. H., \& Eberz, A. (2000). Predicting research interest among rehabilitation counseling students and faculty. Rehabilitation Counseling Bulletin, 44(1), 48-55.

[13] Bennett, C. K. (1994, Winter (EJ482568).). Promoting Teacher Reflection through Action Research: What Do
Teachers Think? Journal of Staff Development., 15(1), 34-38.

[14] Lei, S. A. (2008, June 22). Factors changing attitudes of graduate school students toward an introductory research methodology course. Education. http://www.articlearchives .com/education-training/education-systems-institutions/960 215-1.html adresinden alınd 1

[15] Kart, A., \& Gelbal, S. (2014). Öğretmen Adaylarının Bilimsel Araştırma Öz Yeterlik Algılarının İkili Karşılaştırmalı Yargılar Yöntemiyle Belirlenmesi. Eğitimde ve Psikolojide Ölçme ve Değerlendirme Dergisi, 5(1), 12-23.

[16] Bozanoğlu, İ. (2004). Akademik Güdülenme Ölçeği: Geliştirmesi, Geçerliği, Güvenirliği. Ankara Üniversitesi Eğitim Bilimleri Fakültesi Dergisi, 37(2), 83-98.

[17] Büyüköztürk, Ș. (1997). Araștırmaya Yönelik Kayg1 Ölçeğinin Geliştirilmesi. Kuram ve Uygulamada Eğitim Yönetimi Dergisi, 3(4), 453-464.

[18] Güvenç, B. (1997). Eğitim, Sistem ve Eğitim Sistemi Üzerine. Nasıl Bir Eğitim Sistemi: Güncel Uygulamalar ve Geleceğe İlişskin Öneriler. Ĕgitim Sempozyumu, (s. 261-272). İzmir.

[19] Köklü, N. (1992) Araştırmaya Yönelik Bir Tutum Ölçeğinin Geliştirilmesi. 86, Ankara: Eğitim ve Bilim, Cilt 16, s. 27-36. 